\title{
HUBUNGAN KONFORMITAS DAN HARGA DIRI DENGAN PERILAKU KONSUMTIF PADA REMAJA PUTRI DI KOTA DENPASAR
}

\author{
Made Indah Yuliantari dan Yohanes Kartika Herdiyanto \\ Program Studi Psikologi, Fakultas Kedokteran, Universitas Udayana \\ madeindahyuliantari@gmail.com
}

\begin{abstract}
Abstrak
Perilaku konsumtif pada remaja putri disebabkan oleh faktor internal dan eksternal. Salah satu faktor internal yang menyebabkan remaja berperilaku konsumtif adalah harga diri. Di sisi lain memiliki harga diri yang rendah membuat remaja putrid cenderung mencari teman dan ikut dalam suatu kelompok untuk meningkatkan harga dirinya. Selain itu adanya faktor eksternal yaitu konformitas dalam kelompok remaja menyebabkan seseorang bertindak sesuai dengan apa yang dilakukan oleh teman kelompoknya, karena ingin selaras dengan norma-norma yang diharapkan oleh kelompok (Sarwono, 2002). Perilaku konsumtif apabila tidak dikontrol akan berdampak pada remaja itu sendiri, seperti memiliki sifat boros, memunculkan sifat yang tidak produktif, dan juga menimbulkan terjadinya tindak kejahatan karena seseorang akan menghalalkan segala cara untuk mendapatkan barang yang diinginkan. Selain itu remaja masih pada masa pencarian identitas diri yang didukung oleh teman sebayanya. Dalam hal ini erat kaitannya dengan konformitas dan harga diri, sehingga hipotesis dalam penelitian ini adalah hubungan antara konformitas dan harga diri dengan perilaku konsumtif pada remaja putri di Kota Denpasar.

Penelitian ini menggunakan metode kuantitatif dengan subjek penelitian sebanyak 286 remaja putri yang duduk di kelas X dan XI pada SMAN di Denpasar yang dipilih dengan teknik pengambilan sampel stratified random sampling. Data diperoleh dengan menggunakan skala konformitas (Reliabilitas alpha 0,901), skala harga diri yang diadaptasi dari Wardhani (2009) (Reliabilitas alpha 0,939), dan skala perilaku konsumtif (Reliabilitas alpha 0,900). Hasil penelitian menyatakan bahwa terdapat hubungan yang signifikan antara konformitas dan harga diri dengan perilaku konsumtif pada remaja putri di Kota Denpasar $(\mathrm{R}=0,407 ; \mathrm{r} 2=0,165)$, menggunakan analisis regresi ganda. Secara parsial menunjukkan terdapat hubungan positif yang signifikan antara konformitas dengan perilaku konsumtif pada remaja putri di Kota Denpasar $(\mathrm{r}=0,408)$; serta terdapat hubungan negatif yang signifikan antara harga diri dengan perilaku konsumtif pada pada remaja putri di Kota Denpasar $(r=-0,124)$.
\end{abstract}

Kata Kunci: konformitas, harga diri, perilaku konsumtif

\begin{abstract}
Female teenager conformity behavior is caused by several factors, which is internal factor and external factor. One of the internal factor that caused female teenager has consumptive behavior is prestige. In the other hand, having a low prestige makes female teenager tense to make friends and join a certain group in accordance to lifting their prestige. There is a conformity factorin a teenager group. That result in one's behavior which is based on their mate in that group. Because they want have a same norms which is expected with their group (Sarwono, 2002). If they can't control consumptive behavior, it will give them bad impact such as wasteful, unproductive, a crime where a person will do something. On the other hand teenager is stage where a person tries to find their own identity through their friend of the same age. This will be very much related to conformity and self esteem female teenager consumptive behavior in Denpasar. There is a positive relationship between conformity and female teenager consumptive behavior and also there is a negative relationship between self esteem and female teenager consumptive behavior in Denpasar.

This study was used quantitative method. There were 286 female teenager start from 10 and 11 grade student in Denpasar senior high school. They were selected by stratified random technique sampling. The data was obtain by using conformity scale (Reliability alpha 0,901), self esteem scale which was adopted by Wardhani (2009) (Reliability alpha 0,939), and consumptive behavior scale (Reliability alpha 0,900).

The result of this study was showed there was a significant relationship between conformity and self esteem female teenager consumptive behavior in Denpasar $(\mathrm{R}=0,407 ; \mathrm{r} 2=0,165)$, by using multiple regression analysis. Partially there was a positive significant relationship between conformity and teenager consumptive behavior in Denpasar ( $\mathrm{r}=$ 0,408 ); and also there was negative significant relationship between self esteem and female consumptive behavior in Denpasar $(r=-0,124)$.
\end{abstract}

Keyword: Conformity, Self Esteem, Consumptive Behavior. 


\section{LATAR BELAKANG}

Kota Denpasar merupakan salah satu kota yang sedang berkembang di Negara Indonesia. Salah satu perkembangannya terlihat dari segi perekonomian. Hal itu ditunjukkan dari data yang didapat dari berita resmi statistik Provinsi Bali tahun 2013, pertumbuhan perekonomian Provinsi Bali tumbuh sebesar 6,71 persen, sumbangan terbesar dari Kota Denpasar sebesar 1,53 persen dan Kabupaten Badung sebesar 1,52 persen. Kondisi ini memcerminkan bahwa kondisi perekonomian Bali sangat tergantung pada perekonomian kedua wilayah tersebut. Kontribusi Kota Denpasar dalam bidang perekonomian tidak terlepas dari perannya sebagai Ibu Kota Provinsi Bali yang merupakan pusat aktivitas perekonomian dan perdagangan.

Jenis kegiatan perdagangan di Kota Denpasar dibedakan antara pasar umum, pertokoan dan pasar swalayan. Jumlah toko dan kios mencapai 5.056 buah sedangkan pasar swalayan sampai saat ini ada 18 buah (Dinas Kominfo Kota Denpasar, 2014). Pertumbuhan toko-toko maupun mal yang tersebar di daerah Kota Denpasar maupun pada Kabupaten Badung terlihat meningkat setiap tahunnya. Sebagai contohnya pertumbuhan distribution outlet atau distro yang terletak di kawasan Desa Panjer, Denpasar Selatan. Menurut Dwi (2013), pertumbuhan distro di kawasan itu meningkat sejak 5 tahun terakhir, sampai saat ini terdapat sekitar 40 distro di kawasan Panjer. Selain distro, pembangunan mal-mal besar yang ada di wilayah Badung dari setiap tahunnya juga mengalami peningkatan.

Tersedianya tempat perbelanjaan yang sebagian besar tersebar pada kawasan Denpasar dan Badung, membuat akses berbelanja semakin mudah dan praktis. Hal tersebut membuat tren atau gaya hidup baru bagi masyarakat, khususnya bagi remaja. Usia remaja merupakan sumber yang potensial, karena dilihat dari karakteristik remaja yang masih terbilang labil dan mudah terperngaruh, sehingga mengakibatkan munculnya berbagai gejala dalam perilaku membeli yang tidak wajar (Zebua \& Nurdjayadi dalam Kiliwastisia, 2003).

Seperti pengamatan yang dilakukan pada salah satu mal di Jakarta oleh Purkasih (2008), hasil yang didapat yaitu kebanyakan pengunjung yang datang ke mal masih berada pada usia remaja dan kebanyakan remaja tertarik pada diskon yang ditawarkan oleh salah satu kios barang bermerk di mal tersebut.

Melihat perkembangan zaman secara keseluruhan, masyarakat Indonesia saat ini mengalami era perubahan dari masyarakat modern menuju masyarakat post modern. Era masyarakat post modern selain ditandai dengan munculnya masyarakat yang bergantung pada informasi juga berkembang menjadi masyarakat konsumsi. Hal ini ditandai dengan perkembangan gaya hidup masyarakat Indonesia yang cenderung konsumtif untuk membeli berbagai barang atau komoditas (Kristiana, 2013).

Perilaku konsumtif yaitu perilaku berbelanja yang tidak lagi berdasarkan pada pertimbangan yang rasional, melainkan karena adanya keinginan yang sudah mencapai taraf yang sudah tidak rasional lagi (Sumartono, 2002). Dahlan dalam Lina dan\& Rosyid, (1997), mengatakan bahwa perilaku konsumtif yaitu penggunaan segala hal yang dianggap paling mahal yang memberikan kepuasan dan kenyamanan fisik sebesar-besarnya serta adanya pola hidup yang dikendalikan dan didorong oleh semua keinginan untuk memenuhi hasrat kesenangan semata-mata.

Remaja kini banyak terjebak dalam kehidupan konsumtif, dengan rela mengeluarkan uangnya untuk menuruti segala keinginan, bukan kebutuhan, dalam kesehariannya remaja menghabiskan uang mereka untuk membeli makanan, pakaian, perangkat elektronik, hiburan seperti menonton film dan sebagainya. Semua ini dilakukan remaja kebanyakan hanya untuk ajang pamer dan gengsi, remaja yang dalam pergaulanya dikelilingi oleh remaja lain yang juga berperilaku konsumtif maka remaja tersebut akan mengikuti gaya, penampilan, seolah tidak mau kalah dari temannya (Maulana, 2013).

Perilaku konsumtif yang dialami remaja ini adalah sebuah masalah bagi kehidupan yang dikemudian hari didalam kehidupan masyarakat dan khususnya pada remaja, karena cenderung para remaja tidak menanamkan sifat untuk hidup hemat, dan sifat produktif, dari hidup berperilaku konsumtif yang berlebihan akan mengakibatkan hal yang lebih besar nilai negatif contohnya antara lain: 1) Sifat boros, yang hanya menghambur-hamburkan uang dalam arti hanya menuruti keinginan belanja dan keinginan semata. 2) Kesenjangan atau ketimpangan sosial, artinya dikalangan masyarakat terdapat kecemburuan, rasa iri, dan tidak suka di dalam lingkungannya berada. 3) Tindakan kejahatan, artinya seseorang menghalalkan berbagai cara untuk mendapatkan barang yang diinginkannya. 4) Akan memunculkan orang-orang yang tidak produktif, dalam arti tidak dapat menghasilkan uang melainkan hanya memakai dan membelanjakan (Wahyudi, 2013).

Terdapat faktor-faktor yang dapat memengaruhi seorang remaja untuk berperilaku konsumtif, diantaranya yaitu membeli barang dan jasa bukan sekedar nilai manfaatnya atau karena terdesak kebutuhan, melainkan dipengaruhi sebuah gaya hidup konsumtif yang didorong gengsi agar tidak disebut ketinggalan jaman atau sebagai tanda dari status sosial seseorang (Kristiana, 2013). Selain itu seseorang akan lebih percaya diri bila dari ujung kepala sampai ujung kaki menggunakan barang yang serba mahal dan up to date, sehingga tidak dianggap kuno atau kampungan (Setiana, 2013). 
Selain itu ada juga faktor eksternal dan internal yang memengaruhi munculnya perilaku konsumtif pada remaja yaitu faktor eksternal yang berpengaruh pada perilaku konsumtif individu adalah kebudayaan, kelas sosial, kelompok-kelompok sosial dan referensi serta keluarga. Khususnya kelompok-kelompok sosial dan kelompok referensi, memberikan pengaruh terhadap perilaku konsumtif pada remaja, seseorang akan berperilaku konsumtif sesuai dengan yang dilakukan oleh kelompok referensinya. Kelompok referensi pada usia remaja sangat penting, karena remaja merasa mendapat pengakuan dari kelompok tersebut terhadap individu yang ada di dalam kelompok (Loc dalam Sumartono, 2002).

Kelompok referensi atau kelompok sebaya pada remaja membuat remaja menjadi sangat tergantung kepada teman sebagai sumber kesenangannya dan keterikatannya dengan teman sebaya begitu kuat. Di dalam pembentukan kelompok juga akan diikuti dengan adanya perilaku konformitas kelompok, di mana remaja akan menyesuaikan dan menyatu dengan kelompok agar dapat diterima oleh kelompoknya (Marheni dalam Soetjiningsih, 2004).

Sesuai dengan definisi konformitas dari Sarwono (1995) yaitu usaha individu untuk selalu selaras dengan norma-norma yang diharapkan oleh kelompok, maka a

Adanya faktor konformitas dalam kelompok remaja menyebabkan seseorang bertindak sesuai dengan apa yang dilakukan oleh teman kelompoknya, karena ingin selaras dengan norma-norma yang diharapkan oleh kelompok (Sarwono, 2002). Dalam kelompok tidak hanya memberikan pengaruh yang positif saja, tetapi banyak juga hal-hal yang negatif yang memengaruhi remaja dalam bertindak, seperti memengaruhi pola konsumsi pada usia remaja. (Santrock, 2007). Berikut merupakan sebagian wawancara yang dilakukan peneliti dengan remaja terkait dengan perilaku konsumtif.

Seperti yang diakui oleh Tara berikut ini:

"Mengikuti yang dipakai sama temen-temen sekelompok........masa dia bagus, bagus, bagus, kita sendri yang jelek kan timpang gitu. Misalnya eh...aku punya karet yang dari kain-kain itu, eh ayok-ayok kembaran yok. Cus cus beli. Ya aku sama Gek Arik biasanya kayak gitu. Yang lagi jadi trend gitu lho, banyak yang makek. Misalnya sekarang lagi zaman pakek sepatu New Balance yang lain pengen dah beli." (Yuliantari, 2014).

Selain faktor eksternal yang sudah disebutkan, terdapat faktor internal yang menyebabkan remaja berperilaku konsumtif yaitu faktor internal yang terdapat dalam diri seperti motivasi, harga diri, observasi, proses belajar, kepribadian dan konsep diri. Harga diri merupakan salah satu bagian dari terbentuknya gambaran tentang diri seseorang. Pada usia remaja merupakan tahap awal memulai untuk menyadari tentang gambaran dirinya, yang memengaruhi pengetahuan seseorang terhadap dirinya (Myers, 2012).

Clemes (1995) menyatakan bahwa harga diri adalah rasa nilai dari diri individu yang berasal dari seluruh pikiran, perasaan, sensasi dan pengalaman yang telah individu kumpulkan sepanjang hidup individu yang merupakan dasar bagi pertumbuhan positif dalam hubungan kemanusiaan, belajar kreativitas dan tanggung jawab pribadi. Harga diri yang rendah disebutkan menjadi faktor yang memengaruhi seseorang untuk lebih melakukan hal menurutnya dianggap ideal meskipun dianggap tidak ideal bagi lingkungan masyarakat untuk menutupi rasa tidak berharganya dirinya.

Memiliki harga diri yang rendah membuat remaja cenderung mencari tempat untuk meningkatkan harga dirinya seperti mencari teman dan ikut dalam suatu kelompok. Masuk dalam kelompok tertentu selain dapat meningkatkan harga dirinya yaitu untuk memenuhi rasa pengakuan dan penerimaan dirinya dengan orang lain. Akibat harga diri yang rendah remaja kurang memiliki nilai dan sikap yang demokrakis serta orientasi yang kurang realistis sehingga remaja mudah dibujuk dan dipengaruhi oleh teman-temannya agar dapat diterima dan mendapatkan pengakuan dari kelompoknya (Coopersmith, 1967; Baumeister dalam Novliadi, 2009).

Kebanyakan dari remaja putri sering mengeluhkan atau tidak puas terhadap keadaan tubuhnya, misalnya badan yang tidak ideal atau yang lainnya. Remaja putri yang kurang puas terhadap dirinya pada saat berada pada kelompoknya tersebut, memiliki kecenderungan untuk menutupi kekurangan yang ada pada dirinya. Salah satu cara untuk menutupi kekurangannya tersebut adalah dengan membeli barangbarang yang dianggap dapat meningkatkan harga dirinya. Akan tetapi kebiasaan berbelanja yang dialami remaja membuat remaja lepas kontrol untuk membedakan mana kebutuhan mana keinginan. Hal tersebut membuat remaja mempunyai kecenderungan untuk menimbulkan perilaku konsumtif (Wahyudi, 2013).

Pada kenyataannya remaja putri lebih memenuhi keinginan daripada kebutuhan yang ada. Konformitas yang ada pada suatu kelompok dan juga harga diri dari seseorang mendorong remaja putri untuk menghabiskan uangnya untuk membeli barang-barang yang tidak dibutuhkan sehingga menumbuhkan perilaku konsumtif tersebut. Berdasarkan hal tersebut di atas maka penulis tertarik untuk melakukan penelitian dengan hipotesis ada hubungan konformitas dan harga diri dengan perilaku konsumtif pada remaja putri di Kota Denpasar, ada hubungan yang positif antara konformitas dan perilaku konsumtif pada remaja putri di Kota Denpasar, dan ada hubungan negatifve antara harga diri dan perilaku konsumtif pada remaja putri di Kota Denpasar.

\section{METODE}




\section{Variabel dan definisi operasional}

Variabel diartikan sebagai segala sesuatu yang akan menjadi objek pengamatan penelitian merupakan faktor-faktor yang berpengaruh dalam suatu penelitian atau gejala yang diteliti (Suryabrata, 2000). Penelitian ini menggunakan tiga variabel, yaitu Konformitas dan Harga Diri sebagai variabel bebas dan Perilaku Konsumtif sebagai variabel tergantung.

Definisi operasional variabel penelitian merupakan batasan atau spesifikasi dari variabel-variabel penelitian yang secara konkret berhubungan dengan realitas yang akan diukur dan merupakan manifestasi dari hal-hal yang akan diamati dalam penelitian (Suryabrata, 1998).

Definisi operasional dari variabel-variabel penelitian ini, yaitu:

1. Konformitas

Konformitas adalah perubahan sikap seseorang untuk menyesuaikan pandangan dengan tujuan menyelaraskan dengan norma-norma yang berlaku di kelompoknya tanpa ada pemikiran yang mandiri.

Aspek-aspek Konformitas yaitu kepercayaan terhadap kelompok, kepercayaan yang lemah terhadap penilaian sendiri, rasa takut terhadap celaan sosial, takut menjadi orang yang menyimpang dan ketaatan atau kepatuhan. serta akan diukur dengan menggunakan skala konformitas yang dibuat sendiri oleh peneliti.

2. Harga Diri

Harga diri adalah penilaian individu terhadap dirinya sendiri secara positif atau negatif yang dipengaruhi oleh hasil interaksinya dengan orang-orang yang penting dilingkungannya serta dari sikap, penerimaan, penghargaan, dan perlakuan orang lain terhadap dirinya Aspek-aspek Harga Diri terdiri dari self values, leadership popularity, family parents, dan achievement, serta akan diukur dengan menggunakan skala harga diri yang diadaptasi dari penelitian oleh Wardhani (2009).

\section{Perilaku konsumtif}

Perilaku konsumtif adalah suatu tindakan pembelian atau penggunaan produk yang di dasarkan pada keinginan untuk memenuhi kesenangan, kepuasan dan kenyamanan fisik bukan berdasarkan kebutuhan dan pembelian suatu produk sebagian besar dipengaruhi oleh faktor di luar kebutuhan diri. Aspekaspek perilaku konsumtif terdiri dari impulsive, non-rational, dan wasteful, serta akan diukur dengan menggunakan skala perilaku konsumtif yang dibuat sendiri oleh peneliti.

\section{Karakteristik responden}

Populasi adalah wilayah generalisasi yang terdiri atas objek atau subjek yang mempunyai kuantitas dan karakteristik tertentu yang ditetapkan oleh peneliti untuk dipelajari dan kemudian ditarik kesimpulannya (Sugiono, 2008). Populasi yang ditargetkan dalam penelitian ini adalah remaja putri yang berusia 15-18 tahun. Sementara populasi terakses dalam penelitian ini adalah remaja putri yang bersekolah di sekolah menengah atas negeri di Denpasar. Karakteristik populasi dalam penelitian ini, yaitu remaja putri, rentang usia 15 sampai dengan 18 tahun dan duduk pada kelas $\mathrm{X}$ dan XI sekolah menengah atas di Kota Denpasar.

Sampel penelitian diambil dengan metode pengambilan sampel secara acak dengan menggunakan sStratified random sampling. Stratified random sampling yaitu suatu teknik sampling yang digunakan apabila populasinya berstrata (Sugiyono, 2011). Populasi penelitian ini terletak di Kota Denpasar yang terdiri dari 8 Sekolah Menengah Atas Negeri (SMAN), kemudian peneliti melakukan pengundian secara acak terhadap semua SMAN Sekolah Menengah Atas Negeri tersebut sampai terpilih 4 sekolah.

Jumlah total populasi dalam penelitian ini sebanyak 1593 siswi. Peneliti mengacu pada tabel King dalam Sugiyono (2011) yang menjelaskan bahwa dengan jumlah populasi sebanyak 1.593 orang, bila menggnakan taraf kepercayaan $5 \%$, maka minimal sampel yang digunakan dalam penelitian ini adalah sebanyak 286 orang.

\section{Tempat Penelitian}

Proses pengambilan sampel penelitian dilakukan dengan cara melakukan pengundian secara acak terhadap 8 SMAN, kemudian peneliti melakukan pengundian secara acak terhadap semua SMANekolah Menengah Atas Negeri tersebut sampai terpilih 4 sekolah yaitu SMAN 1, SMAN 3, SMAN 4, dan SMAN 5 Denpasar, maka, penelitian dilaksanakan pada bulan Mei 2014 di 4 SMA Negeri ada di Denpasar.

\section{Alat Ukur}

Alat ukur dalam penelitian ini adalah skala penelitian, yaitu dengan model skala Likert. Skala Likert digunakan untuk mengukur sikap, pendapat, dan persepsi seseorang atau sekelompok orang mengenai fenomena sosial (Sugiyono, 2012). Skala yang digunakan adalah (1) skala kKonformitas, (2) skala hHarga dDiri, dan (3) skala pPerilaku kKonsumtif. Masing-masing skala terdiri dari pernyataan-pernyataan yang nantinya akan direspon oleh responden. Item-item dalam skala merupakan pernyataan dengan empat pilihan jawaban, yaitu sangat tidak setuju, tidak setuju, setuju, sangat setuju. Skala disajikan dalam bentuk pernyataan favorable dan unfavorable. Skor yang diberikan bergerak dari 1 sampai 4. Bobot penilaian untuk favorable yaitu: Sangat Tidak Setuju (STS) $=1$, Tidak Setuju $(\mathrm{TS})=2$, Setuju $(\mathrm{S})=3$, Sangat Setuju $(\mathrm{SS})=4$, sedangkan bobot penilaian untuk pernyataan unfavorable yaitu: Sangat Tidak Setuju (STS) $=4$, Tidak Setuju $($ TS $)=3$, Setuju $(S)=2$, Sangat Setuju $(S S)=1$. 
Validitas skala yang digunakan dalam penelitian ini adalah validitas isi yang terdiri dari validitas muka dan validitas logis. Validitas isi merupakan validitas yang diestimasi melalui pengujian terhadap isi tes dengan analisis rasional atau melalui professional judgment. Validitas muka merupakan validitas yang didasarkan pada penilaian terhadap format penampilan skala, sedangkan validitas logis melihat sejauh mana isi skala merupakan representasi dari ciri-ciri atribut yang hendak diukur (Azwar, 2010). Validitas isi dalam penelitian ini dilakukan dengan menggunakan analisis dan seleksi item berdasarkan evaluasi kualitatif. Evaluasi ini bertujuan untuk menguji item yang ditulis sesuai dengan apa yang hendak diungkapkannya dan menguji item agar sesuai dengan kaidah penulisan (Azwar, 2012). Validitas isi dalam penelitian ini dianalisis melalui professional judgment.

Uji kesahihan butir item dalam penelitian ini dinyatakan oleh koefisien korelasi item total dan korelasi item antar aspek dengan batasan minimum $>0,25$.

Sementara itu, reliabilitas dalam penelitian ini diuji dengan menggunakan reliabilitas Formula Alpha berdasarkan teknik konsistensi internal yang dirumuskan oleh Cronbach (Azwar, 1998). , dengan bantuan program komputer Statistical for Social Science (SPSS). Metode Alpha Cronbach ini digunakan untuk menghitung reliabilitas skala yang mengukur sikap atau perilaku. Kriteria suatu skala dikatakan reliabel dengan menggunakan teknik ini, apabila koefisien reliabilitas menunjukan angka lebih dari 0,6 (Siregar, 2013).

Uji coba skala dilakukan pada semua skala penelitian, yaitu skala Konformitas, Harga Diri, dan Perilaku Konsumtif. Uji coba skala skala Konformitas, Harga Diri, dan Perilaku Konsumtif dilaksanakan dengan menyebar 40 skala kepada 40 siswi kelas $\mathrm{X}$ dan XI pada SMA Negeri 5 Denpasar. Jumlah item yang valid dari skala konformitas adalah sebanyak 27 item dari 50 item yang di uji cobakan. Rentang koefisien korelasi item totalnya bergerak dari 0,2610,650 dengan koefisien reliabilitas sebesar 0,901. Pada skala Harga Diri jumlah item yang valid adalah sebanyak 36 item dari 38 item yang diuji cobakan. Rentang koefisien korelasi item totalnya bergerak dari 0,333 - 0,715 dengan koefisien reliabilitas sebesar 0,939 dan Jumlah item yang valid dari skala perilaku konsumtif adalah sebanyak 21 item dari 30 item yang di uji cobakan. Rentang koefisien korelasi item totalnya bergerak dari 0,289 - 0,793 dengan koefisien reliabilitas sebesar 0,900 .

\section{Metode pengumpulan data}

Pada penelitian ini, pengumpulan data dilakukan dengan pengukuran terhadap tiga variabel penelitian, yaitu Konformitas, Harga Diri dan Perilaku Konsumtif. Ketiga variabel tersebut diukur dengan menggunakan skala penelitian (skala Konformitas, Skala Harga Diri, dan Skala Perilaku
Konsumtif). Pengumpulan data dilakukan dengan menyebar skala penelitian kepada siswi kelas X dan XI pada SMAN 1, SMAN 3, SMAN 4, dan SMAN 5 Denpasar.

\section{Analisa data}

Metode analisis data yang digunakan adalah analisis statistik dan untuk menganalisis data penelitian yang telah diperoleh menggunakan analisis regresi ganda dan korelasi parsial dengan program analisis statistik komputer yaitu Statistical Package for Social Science (SPSS). Regresi ganda digunakan untuk menentukan bentuk hubungan konformitas dan harga diri dengan perilaku konsumtif pada remaja putri di Kota Denpasar sekaligus melihat kontribusinya. Korelasi parsial dilakukan untuk melihat hubungan masing-masing variabel bebas yaitu konformitas dan harga diri.

Peneliti juga melakukan intepretasi skor data penelitian. Data penelitian akan dikategorisasikan berdasarkan skor total skala masing-masing subjek. Penentuan kategori skor skala dilakukan dengan menggunakan nilai mean teoritis dan standar deviasi. Kategori skala konformitas, harga diri dan perilaku konsumtif akan dibagi menjadi 5 kategori jenjang yang berbeda, dengan batasan skor pada masing-masing kategori dapat ditentukan dengan rumus penghitungan sebagai berikut:

\begin{tabular}{cc} 
Rumus Kategorisasi Skor & Tabel 1 \\
\hline Skor & Kategorisasi \\
\hline $\mathrm{X} \leq(\mu-1,5 \sigma)$ & Sangat Rendah \\
$(\mu-1,5 \sigma)<\mathrm{X} \leq(\mu-0,5 \sigma)$ & Rendah \\
$(\mu-0,5 \sigma)<\mathrm{X} \leq(\mu+0,5 \sigma)$ & Sedang \\
$(\mu+0,5 \sigma)<\mathrm{X} \leq(\mu+1,5 \sigma)$ & Tinggi \\
$(\mu+1,5 \sigma)<\mathrm{X}$ & Sangat Tinggi \\
\hline
\end{tabular}

\section{HASIL PENELITIAN}

Sebelum melakukan uji hipotesis, adapun syarat yang harus dipenuhi sebelum menggunakan metode regresi ganda yaitu dengan melakukan uji asumsi yang meliputi uji normalitas, uji linearitas, dan uji multikolinieritas. Uji asumsi memiliki tujuan untuk memeriksa apakah data yang terkumpul memenuhi syarat untuk melakukan pengkorelasian atau tidak. Uji normalitas sebaran data pada penelitian ini menggunakan menggunakan uji statistik non-parametrik KolmogorovSmirnov (K-S) yang secara komputasi diolah melalui fasilitas yang ada pada program SPSS. Berdasar hasil pengujian diperoleh bahwa sebaran data pada variabel Konformitas, Harga Diri dan Perilaku Konsumtif bersifat normal (Asymp. Sig. (2-tailed) ketiga variabel penelitian memiliki probabilitas sebesar 0,258 (p>0,05))). Sedangkan pada uji linieritas didapat hasil bahwa hubungan antara skor variabel Konformitas dan Perilaku Konsumtif telah menunjukkan adanya garis yang linier $(\mathrm{p}<0,05)$. pada uji linieritas Harga Diri dan Perilaku Konsumtif didapat hasil yang menunjukkan adanya garis yang linier $(\mathrm{p}<0,05)$. 
Berdasarkan pengumpulan data yang dilakukan pada 286 responden, didapat hasil bahwa sebagian besar responden berusia 16 tahun $(55,94 \%)$, Rata-rata siswi yang mempunyai uang saku berata-rata Rp. 100.000,00 - Rp. 300.000,00 sebanyak 107 siswi dan juga uang saku berata-rata Rp.300.000,00 - Rp.500.000,00 sebanyak 107 siswi.

Selanjutnya, untuk melihat hubungan Konformitas, Harga Diri dan Perilaku Konsumtif, peneliti melakukan analisis regresi ganda dengan bantuan SPSS 17.00. Berikut ini adalah hasil dari analisis regresi ganda yang terdiri dari uji signifikansi garis regresi, uji signifikansi parameter individual, dan besarnya sumbangan efektif variabel konformitas, harga diri dan prilaku konsumtif:

Tabel

\begin{tabular}{lccccc}
\multicolumn{6}{c}{ Hasil Uji Signifikansi Garis Regresi } \\
\hline \multicolumn{1}{c}{ Model } & $\begin{array}{c}\text { Sum of } \\
\text { Squares }\end{array}$ & Df & Mean Square & F & Sig. \\
\hline Regression & 3355.082 & 2 & 1677.541 & 28.014 & $.000^{6}$ \\
$1 \quad$ Residual & 16946.694 & 283 & 59.882 & & \\
Total & 20301.776 & 283 & & & \\
\hline a Dependent Variabel: Perilaku Konsumtif & & & \\
\hline
\end{tabular}

bredictors: (Constat), Konformitas, Harga Diri

Uji Signifikansi Garis Regresi dilakukan untuk mengetahui apakah model regresi dapat digunakan untuk memprediksi variabel tergantung (Santoso, 2005) dan untuk menunjukan apakah variabel bebas yang dimasukan ke dalam model regresi memiliki hubungan dengan variabel tergantung (Ghozali, 2013). Pada tabel 2 Hasil Uji Signifikansi Garis Regresi diatas dapat dilihat bahwa F Hitung sebesar 28.014 dengan nilai signifikansi sebesar 0,000. Oleh karena signifikansi lebih kecil dari 0,01 ( $\mathrm{p}<0,05)$, maka dapat diartikan bahwa model regresi dapat dipercaya untuk meramalkan kontribusi variabel bebas yaitu konformitas dan harga diri dalam memprediksi variabel tergantung yaitu perilaku konsumtif.

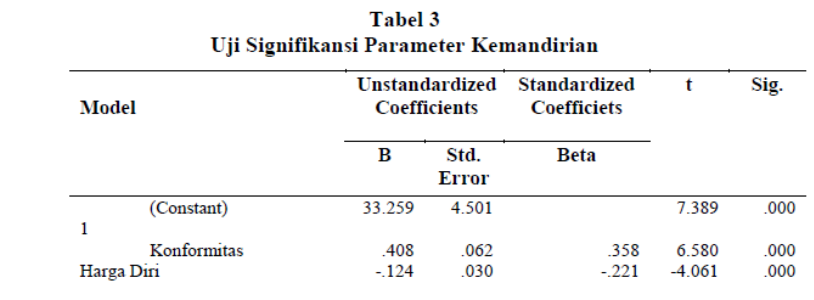

a. Dependent Variable: Perilaku Konsumtif

Seberapa jauh pengaruh variabel bebas secara individual dalam menerangkan variasi variabel tergantung dapat dijelaskan melalui hasil uji regresi ganda. Melalui tabel ini terlihat juga arah hubungan yang terjadi dan apakah hubungan yang terjadi merupakan hubungan yang bersifat sebab akibat (Ghozali, 2012). Arah hubungan konformitas dengan perilaku konsumtif dapat dilihat dari nilai koefisien regresi (B). Pada tabel, nilai $\mathrm{B}$ bersifat positif $(\mathrm{B}=0,408)$ artinya setiap adanya penambahan dari variabel konsumtif maka akan meningkatkan perilaku konsumtif.

Sebaliknya arah hubungan harga diri dengan perilaku konsumtif dapat dilihat juga dari nilai koefisien regresi (B). Pada tabel, nilai $\mathrm{B}$ bersifat negatif $(\mathrm{B}=-0,124)$. Negatif $(-)$ berarti bahwa variabel bebas dan variabel terikat memiliki hubungan yang berkebalikan. Semakin tinggi harga diri, maka tingkat perilaku konsumtif akan semakin rendah. Begitu pula sebaliknya, apabila semakin rendah harga diri, maka tingkat perilaku konsumtif akan semakin tinggi.

Nilai probabilitas (p) pada taraf signifikansi 5\% yang terdapat pada tabel uji signifikansi menunjukkan angka 0.000 ( $\mathrm{p}<0.05$ ), artinya konformitas memiliki hubungan yang signifikan dengan perilaku konsumtif, yang mana gejala perilaku konsumtif dapat diduga sebagai suatu gejala sebab akibat. Hubungan ini diyakini sebagai gejala sebab dan bukan merupakan gejala random karena dapat diramalkan apabila terjadi kenaikan 1 nilai pada variabel konformitas maka nilai perilaku konsumtif akan naik sebanyak 0,408. Nilai probabilitas pada harga diri menunjukkan angka 0,000 ( $\mathrm{p}<$ $0,05)$, artinya harga diri memiliki hubungan yang signifikan dengan perilaku konsumtif.

Besarnya sumbangan variabel bebas konformitas dan harga diri terhadap variabel tergantung perilaku konsumtif dapat dilihat pada tabel sumbangan efektif berikut:

\begin{tabular}{|c|c|c|c|c|}
\hline \multicolumn{5}{|c|}{$\begin{array}{c}\text { Tabel } 4 \\
\text { Hasil Sumbangan Efektif Variabel Konformitas dan Harga Diri } \\
\text { Terhadap Variabel Perilaku Konsumtif }\end{array}$} \\
\hline Model & $\mathbf{R}$ & R Square & $\begin{array}{c}\text { Adjusted R } \\
\text { Square }\end{array}$ & $\begin{array}{l}\text { Std. Error of } \\
\text { the Estimate }\end{array}$ \\
\hline & $.407^{\mathrm{a}}$ & & 159 & 7.738 \\
\hline
\end{tabular}

a. Predictors: (Constant), Konformitas, Harga Diri

b.Dependent Variabel: Perilaku Konsumtif

Pada kolom R. Square yang menunjukkan angka sebesar 0,165. Angka pada kolom R. Square Sumbangan efektif merupakan angka yang diperoleh dari pengkuadratan nilai R $(0,407)$. Sumbangan efektif atau nilai R. Square dapat diartikan sebagai seberapa besar varian variabel bebas dapat menjelaskan varian variabel tergantung (Santoso, 2005). Dalam penelitian ini, maka sumbangan variabel konformitas dan harga diri terhadap variabel perilaku konsumtif adalah sebesar $16,5 \%$. Sedangkan sumbangan selain dari variabel konformitas dan harga diri terhadap perilaku konsumtif adalah sebesar $83,5 \%$, yang diperoleh dari faktor-faktor lainnya yang tidak dikaji dalam penelitian ini.

Pengkategorisasian responden pada skala konformitas, harga diri, dan perilaku konsumtif diperoleh hasil sebagai berikut: 
Tabel 5

Tabel Kategorisasi Responden pada Skala Konformitas

\begin{tabular}{ccccc}
\hline Variabel & $\begin{array}{c}\text { Rentang } \\
\text { Nilai }\end{array}$ & Kategori & Subyek & Persentase \\
& $\mathrm{X} \leq 47,25$ & Sangat Rendah & 17 orang & $5,94 \%$ \\
\hline Konformitas & $47,25<\mathrm{X} \leq 60,75$ & Rendah & 126 orang & $44,05 \%$ \\
& $60,75<\mathrm{X} \leq 74,25$ & Sedang & 140 orang & $48,95 \%$ \\
& $74,25<\mathrm{X} \leq 87,75$ & Tinggi & 3 orang & $1,04 \%$ \\
$87,75<\mathrm{X}$ & Sangat Tinggi & 0 orang & $0 \%$ \\
\hline & Jumlah & & 286 orang & $100 \%$ \\
\hline
\end{tabular}

Berdasarkan analisis kategorisasi pada skala konformitas pada tabel 5 menunjukan bahwa sebagian besar responden termasuk dalam kategori sedang 48,95\% (140 orang). Hal ini berarti sebagian besar responden memiliki tingkat konformitas yang sedang.

Tabel 6

Tabel Kategorisasi Subyek pada Skala Harga Diri

\begin{tabular}{ccccc}
\hline Variabel & Rentang Nilai & Kategori & Subyek & Persentase \\
\hline \multicolumn{4}{c}{} \\
\hline Harga Diri & $\mathrm{X} \leq 63$ & Sangat Rendah & 6 orang & $2,09 \%$ \\
& $63<\mathrm{X} \leq 81$ & Rendah & 89 orang & $31,11 \%$ \\
& $81<\mathrm{X} \leq 99$ & Sedang & 95 orang & $33,21 \%$ \\
& $99<\mathrm{X} \leq 117$ & Tinggi & 82 orang & $28,67 \%$ \\
& $117<\mathrm{X}$ & Sangat Tinggi & 14 orang & $4,89 \%$ \\
\hline & Jumlah & & 286 orang & $100 \%$ \\
\hline
\end{tabular}

Berdasarkan analisis kategorisasi pada skala harga diri pada tabel 6 menunjukan bahwa sebagian besar responden termasuk dalam kategori sedang 33,21\% (95 orang). Hal ini berarti sebagian besar responden memiliki tingkat harga diri yang sedang.

\begin{tabular}{|c|c|c|c|c|}
\hline Variabel & Rentang Nilai & Kategori & Subyek & Persentase \\
\hline \multirow{6}{*}{ Harga Diri } & $\mathrm{X} \leq 36,75$ & Sangat Rendah & 34 orang & $11,8 \%$ \\
\hline & $36,75<\mathrm{X} \leq 47,25$ & Rendah & 130 orang & $45,45 \%$ \\
\hline & $47,25<\mathrm{X} \leq 57,75$ & Sedang & 98 orang & $34,26 \%$ \\
\hline & $57,75<\mathrm{X} \leq 68,25$ & Tinggi & 21 orang & $7,34 \%$ \\
\hline & $68,25<\mathrm{X}$ & Sangat Tinggi & 3 orang & $1,04 \%$ \\
\hline & Jumlah & & 286 orang & $100 \%$ \\
\hline
\end{tabular}

Berdasarkan analisis kategorisasi pada skala perilaku konsumtif pada tabel 7 menunjukan bahwa sebagian besar responden termasuk dalam kategori rendah 45,45\% (130 orang). Hal ini berarti sebagian besar responden memiliki tingkat perilaku konsumtif yang rendah.

\section{PEMBAHASAN DAN KESIMPULAN}

Berdasarkan hasil uji hipotesis melalui analisis regresi ganda, diperoleh hasil bahwa semua hipotesis diterima, yakni hipotesis mayor $(\mathrm{R}=0,407)$ dan hipotesis minor pertama $(r=0,408, p<0,05)$ serta hipotesis minor kedua $(r=$ $-0,124, \mathrm{p}<0,05)$.

Hipotesis yang pertama yang diterima yaitu ada hubungan antara konformitas dan harga diri dengan perilaku konsumtif pada remaja putri di Kota Denpasar. Dapat diterimanya hipotesis tersebut dilihat dari hasil analisis statistik yang menggunakan teknik analisis regresi ganda.

Hasil uji signifikansi simultan dari analisis regresi yang dilakukan menunjukkan signifikansi sebesar 0,000 ( $\mathrm{p}<0,05)$.
Hal ini menunjukkan bahwa garis regresi dapat dipercaya untuk meramalkan variabel tergantung yakni perilaku konsumtif atau dapat dikatakan konformitas dan harga diri secara bersama-sama berpengaruh terhadap perilaku konsumtif.

Koefisien regresi antara konformitas dan perilaku konsumtif bernilai positif $(B=0,408)$ yang memiliki makna bahwa kedua variabel tersebut searah, artinya jika terjadi peningkatan nilai pada variabel konformitas maka akan terjadi peningkatan pada variabel perilaku konsumtif. Begitu pula sebaliknya, jika terjadi penurunan nilai pada variabel konformitas maka akan terjadi penurunan nilai pada variabel perilaku konsumtif. Angka probabilitas dari tabel uji signifikansi parameter individual menunjukkan angka 0,000 (p $<0,05)$. Nilai probabilitas ini memberi arti bahwa terdapat hubungan yang signifikan antara konformitas dengan perilaku konsumtif.

Hasil komputasi statistik tersebut memberi suatu kesimpulan bahwa hubungan yang terjadi antara konflik konformitas dan perilaku konsumtif merupakan suatu hubungan yang bersifat kausal sehingga bukan merupakan gejala random $(\mathrm{p}=0,000 ; \mathrm{p}$ $<0,05)$. Variabel bebas yaitu konformitas berkedudukan sebagai prediktor dari variabel tergantung yaitu perilaku konsumtif. Hubungan ini dapat diyakini sebagai hubungan yang kausal karena perubahan yang terjadi pada nilai variabel perilaku konsumtif apabila nilai konformitas dinaik-turunkan dapat diramalkan dalam suatu fungsi yaitu setiap terjadi kenaikan 1 nilai pada variabel konformitas, maka nilai perilaku konsumtif akan turun sebanyak 0,408.

Koefisien regresi antara harga diri dan perilaku konsumtif bernilai negatif $(B=-0,124)$ yang memiliki makna bahwa kedua variabel tersebut saling berlawanan arah, artinya jika terjadi peningkatan nilai pada variabel harga diri maka akan terjadi penurunan pada variabel perilaku konsumtif. Begitu pula sebaliknya, jika terjadi peningkatan nilai pada variabel harga diri maka akan terjadi penurunan nilai pada variabel perilaku konsumtif. Angka probabilitas dari tabel uji signifikansi parameter individual menunjukkan angka 0,000 (p $<0,05)$. Nilai probabilitas ini memberi arti bahwa terdapat hubungan yang signifikan antara harga diri dengan perilaku konsumtif.

Hasil komputasi statistik tersebut memberi suatu kesimpulan bahwa hubungan yang terjadi antara konflik harga diri dan perilaku konsumtif merupakan suatu hubungan yang bersifat kausal sehingga bukan merupakan gejala random ( $\mathrm{p}=$ $0,000 ; \mathrm{p}<0,05)$. Variabel bebas yaitu harga diri berkedudukan sebagai prediktor dari variabel tergantung yaitu perilaku konsumtif. Hubungan ini dapat diyakini sebagai hubungan yang kausal karena perubahan yang terjadi pada nilai variabel perilaku konsumtif apabila nilai harga diri dinaik-turunkan dapat diramalkan dalam suatu fungsi yaitu setiap terjadi 
kenaikan 1 nilai pada variabel konformitas, maka nilai perilaku konsumtif akan turun sebanyak 0,124.

Nilai koefisien korelasi (r) dalam penelitian adalah 0,407. Mengacu pada interpertasi koefisien korelasi Sugiyono (2012), dapat diketahui bahwa nilai koefisien korelasi 0,407 berada pada kategori tingkat hubungan yang sedang. Tingkat hubungan yang sedang ini berada pada interval 0,40-0,599. Hubungan antara konformitas dan harga diri pada perilaku konsumtif berada pada tingkat hubungan yang sedang disebabkan oleh siswi yang terpilih menjadi sampel penelitian merupakan siswi yang masuk pada kategori murid dengan prestasi menengah ke atas. Hal ini dapat dilihat dari kualitas sekolah yang terpilih menjadi populasi pada penelitian ini, dalam penelitian ini sekolah yang terpilih yaitu SMAN 1, SMAN 3, SMAN 4, dan SMAN 5 yang merupakan sekolah unggulan dan favorit pada kota Denpasar. Hubungan antara konformitas dan harga diri pada perilaku konsumtif berada pada tingkat hubungan yang sedang disebabkan oleh siswi yang terpiih menjadi sampel peneltian merupakan siswi yang masuk pada kategori murid dengan prestasi menengah ke atas. Hal ini daoat dilihat dari kualitas sekolah yang terpilih yaitu SMAN 1, SMAN 3, SMAN 4, dan SMAN 5 Denpasar yang merupakan sekolah unggulan dan favorit pada kota Denpasar. Hipotesis minor pertama diterima yang berbunyi ada hubungan positif antara konformitas dan perilaku konsumtif pada remaja putri di Kota Denpasar. Pada variabel konformitas pada subjek penelitian tergolong dalam kategori sedang $(48,95 \%)$. Berdasarkan hasil dalam penelitian ini variabel konformitas memiliki hubungan yang positif yang signifikan $(r=0,408, p<0,05)$ dengan perilaku konsumtif.

Berdasarkan nilai korelasi yang signifikan antara konformitas dan perilaku konsumtif, dapat diungkapkan salah satu faktor yang turut berperan dalam pembentukan perilaku konsumtif adalah konformitas. Semakin konform seorang remaja dalam kelompoknya, maka semakin mudah dipengaruhi untuk berperilaku konsumtif. Hal ini sesuai dengan pendapat Rice (dalam Zebua \& Nurdjayadi, 2001) yang menyatakan bahwa remaja putri lebih conform daripada remaja putra, karena remaja putri mempunyai keinginan yang besar untuk menjaga harmonisasi, mencapai persetujuan, dan penerimaan sosial.

Selain itu pada usia remaja, khususnya remaja putri cenderung terikat pada teman-teman atau pada kelompoknya (peer group) (Marheni dalam Soetjiningsih, 2004). Pada saat remaja berperilaku didasarkan oleh harapan dari kelompok maka terjadilah konformitas (Baron dkk, dalam Surya, 1999). Morgan, King dan Robinson (dalam Nindyati \& Indria, 2007) menyebutkan adanya faktor konformitas dalam kelompok membuat remaja cenderung mengubah pandangan atau perilakunya, dengan tujuan untuk menyesuaikan dengan tuntutan norma sosialnya.
Dalam hal ini kelompok teman sebaya merupakan sumber referensi utama bagi remaja dalam hal persepsi dan sikap yang berkaitan dengan gaya hidup (Conger, 1991; Papalia \& Olds, 2001), sehingga remaja yang masih dalam masa transisi mempunyai karakteristik mudah dipengaruhi oleh kelompok teman sebaya (Monks, Knoers, \& Haditomo, 2004). Konformitas pada teman sebaya bagi remaja mempunyai pengaruh yaitu dalam hal perilaku membeli. Hal ini tampaknya tidak terlepas dari keinginan remaja untuk tampil menarik, tidak berbeda dengan teman-temannya dan agar dapat diterima sebagai bagian dari kelompok. Akibatnya remaja terdorong untuk berperilaku konsumtif karena remaja ingin agar penampilan mereka sama dengan teman sebaya dan diterima sebagai kelompok.

Hasil analisa dan kategori empiris data penelitian menunjukkan tingkat konformitas subjek penelitian secara umum berada pada kategori sedang $(48,95 \%)$ dan tingkat perilaku konsumtif subjek penelitian paling banyak berada pada kategori rendah $(45,45 \%)$. Hasil ini sesuai dengan teori perkembangan remaja akhir. Pada usia awal remaja konformitas cenderung meningkat, stabil pada pertengahan usia remaja dan menurun pada akhir masa remaja (Hurlock, 2004). Dalam penelitian ini rentang usia subjek penelitian antara 15-17 tahun dan menunjukkan tingkat konformitas yang sedang. Menurut Santrock (2007), konformitas cenderung jauh lebih kuat pada usia 14-15 tahun atau pada kelas sembilan dan konformitas remaja cenderung menurun dan stabil di akhir masa sekolah menengah atas. Hal ini terjadi karena kesesuaian antara orangtua dan kawan sebaya mulai meningkat di beberapa bidang, selain itu pada usia ini para remaja mulai mengembangkan gaya keputusan yang lebih mandiri dari pengaruh kawan-kawan sebaya dan orangtua.

Hipotesis minor kedua diterima yang berbunyi ada hubungan negatif antara harga diri dan perilaku konsumtif pada remaja putri di Kota Denpasar. Pada variabel harga diri pada subjek penelitian tergolong dalam kategori sedang $(33,21 \%)$. Berdasarkan hasil dalam penelitian ini variabel harga diri memiliki hubungan yang negatif yang signifikan $(\mathrm{r}$ $=-0,124, \mathrm{p}<0,05)$ dengan perilaku konsumtif.

Koefisien regresi (B) antara harga diri dan perilaku konsumtif terdapat korelasi negatif yang signifikan dengan hasil sebesar -0,124 (dengan $\mathrm{p}<0,05$ ) yang bermakna bahwa kedua variabel tersebut saling berkorelasi berlawanan arah, artinya jika terjadi peningkatan nilai pada variabel harga diri maka akan terjadi penurunan nilai pada variabel perilaku konsumtif. Berlaku juga untuk sebaliknya, jika terjadi peningkatan nilai pada variabel harga diri maka akan terjadi penurunan nilai pada variabel perilaku konsumtif. Angka probabilitas dari tabel uji signifikansi parameter individual menunjukkan angka $0,000(\mathrm{p}<0,05)$, ini berarti terdapat hubungan yang signifikan antara harga diri dan perilaku konsumtif. 
Berdasarkan nilai korelasi yang signifikan antara harga diri dan perilaku konsumtif, dapat diungkapkan salah satu faktor yang turut berperan dalam pembentukan perilaku konsumtif selain konformitas adalah harga diri. Hal ini sesuai dengan pendapat Sears, Freedman, dan Peplau (1991) yang menyatakan bahwa harga diri mempunyai pengaruh pada perilaku membeli.

Masa remaja merupakan masa pencarian identitas diri. Pada tahap paling awal, remaja mulai menyadari bagaimana gambaran tentang dirinya. Adanya komponen konsep diri, pengetahuan diri, dan harga diri memengaruhi pengetahuan seseorang akan dirinya (Myers, 2012). Salah satu bagian dalam pembentukan pengetahuan tentang diri yaitu harga diri.

Hakikatnya setiap remaja menginginkan harga diri yang tinggi. Menurut Vaughan \& Hogg (2002) harga diri positif membuat seseorang dapat mengatasi kecemasan, kesepian, dan penolakan sosial. Seseorang yang memiliki harga diri yang tinggi maka akan menunjukkan bahwa remaja semakin merasa diterima dan menyatu dengan orang-orang disekitarnya. Selain itu seseorang yang memiliki harga diri yang tinggi apabila orang tersebut dapat merasa senang dengan kepandaiannya, penampilan, dan lainnya (Myers, 2012). Apabila seseorang memiliki harga diri yang rendah akan menganggap dirinya tidak berharga, menolak dirinya sendiri dan tidak puas dengan keadaan dirinya (Coopersmith, 1967).

Akibat dari harga diri yang rendah pada remaja yaitu remaja mudah untuk dibujuk dan dipengaruhi oleh sesuatu yang menurutnya dapat meningkatkan harga dirinya. Salah satu cara untuk meningkatkan harga diri yaitu dengan membeli barang yang mempunyai arti simbolik sehingga dapat meningkatkan harga dirinya. Harter (dalam Santrock, 2003) menyatakan bahwa terdapat hubungan yang kuat antara penampilan diri dengan harga diri pada remaja. Salah satu dampak dari pembelian barang-barang yang dianggap dapat meningkatkan harga diri tersebut adalah perilaku konsumtif. Seperti pengertian dari perilaku konsumtif yang di paparkan oleh Dahlan (dalam Lina \& Roysid, 1997) perilaku konsumtif yaitu penggunaan segala hal yang dianggap paling mahal yang memberikan kepuasan dan kenyamanan fisik sebesar-besarnya serta adanya pola hidup yang dikendalikan dan didorong oleh semua keinginan untuk memenuhi hasrat kesenangan semata.

Selain untuk meningkatkan harga diri, memakai barangbarang tertentu tersebut dilakukan hanya untuk mendapatkan pengakuan sosial. Santrock (2007) mengemukakan bahwa dukungan dari teman-teman sebaya memberikan pengaruh yang penting bagi harga diri remaja. Hal ini diperkuat dengan pernyataan dari Tambunan (2001) yang menyebutkan keinginan remaja untuk diakui eksistensinya oleh lingkungan dengan berusaha menjadi bagian dari lingkungan itu adalah sangat penting, sehingga kebutuhan untuk diterima dan menjadi sama dengan teman sebaya tersebut menyebabkan remaja berusaha untuk mengikuti berbagai atribut yang sedang trend.

Hasil analisa dan kategori empiris data penelitian menunjukkan tingkat harga diri subjek penelitian secara umum berada pada kategori sedang $(33,21 \%)$ dan tingkat perilaku konsumtif subjek penelitian paling banyak berada pada kategori rendah $(45,45 \%)$. Hasil ini kurang sesuai dengan pendapat dari Santrock (2007) yang menyebutkan harga diri cenderung akan meningkat pada usia remaja pertengahan. Pada kategori sedang pada harga diri ini memungkinkan seseorang memiliki kecenderungan untuk berperilaku konsumtif yang rendah karena pengertian sedang tersebut berada pada titik tengah antara harga diri yang rendah maupun harga diri yang tinggi. Pada kenyataannya remaja putri di Kota Denpasar memiliki tingkat perilaku konsumtif yang rendah. Hal ini dapat terjadi karena banyaknya faktor lain yang memengaruhi harga diri pada seseorang.

Subjek dalam penelitian ini kebanyakan dari subjek berada pada rentang usia 16 tahun $(55,94 \%)$, dimana pada usia ini remaja termasuk dalam kelompok usia remaja pertengahan atau madya (Pikunas, 1976). Pada remaja awal seseorang cenderung mempunyai perasaan rendah diri, akan tetapi harga diri akan meningkat seiring pertambahan usia seseorang.

Pada masa remaja khususnya remaja pertengahan banyak mengalami perkembangan baik dari segi fisik, kognitif, kepribadian, dan sosial. Jika dilihat dari segi kognitif, masa remaja berada pada tahap formal operation, dimana seseorang telah mampu berfikir secara abstrak, mampu memahami bahwa tindakan yang dilakukan saat ini memberikan efek pada masa yang akan datang (Papalia \& Olds, 2001). Jika seorang remaja belum dapat menerapkan pemikiran pada tahap formal information dan masih membawa sifat egosentrisnya maka akan bepengaruh pada pengambilan keputusan yang salah dan cenderung berperilaku seenak hatinya tanpa memikirkan akibatnya.

Berdasarkan hasil analisis data dan pembahasan yang telah dilakukan pada penelitian ini, telah dapat membuktikan 3 hipotesis yang ada yaitu hipotesis mayor dan hipotesis minor yang pertama dan kedua. Adapaun hipotesis mayor dalam penelitian ini yaitu adanya hubungan antara konformitas dan harga diri dengan perilaku konsumtif pada remaja putri di Kota Denpasar. Hipotesis minor dalam penelitian ini yang pertama yaitu adanya hubungan positif antara konformitas dan perilaku konsumtif pada remaja putri di Kota Denpasar dan hipotesis minor yang kedua yaitu adanya hubungan negatif antara harga diri dan perilaku konsumtif pada remaja putri di Kota Denpasar. Besarnya nilai koefisien determinasi (r2) menunjukkan seberapa variabel bebas yaitu konformitas dan harga diri mampu menjelaskan terhadap variabel tergantung yaitu perilaku konsumtif dalam persen sebesar 16,5\% sedangkan sisanya $83,5 \%$ dapat dijelaskan oleh faktor-faktor 
lain yang tidak diteliti dalam penelitian ini. Faktor-faktor lain yang memiliki kontribusi pada perilaku konsumtif yaitu gaya hidup, hadirnya iklan, kartu kredit, kebudayaan dan kebudayaan khusus, kelas sosial, kelompok sosial dan referensi, keluarga, pengamatan dan proses belajar, serta kepribadian dan konsep diri (Suyasa \& Fransisca, 2005; Lina \& Rosyid, 1997) dan faktor lainnya.

Terkait dengan pemaparan di atas, maka bagi remaja, khususnya remaja putri untuk mencegah terjadinya perilaku konsumtif hendaknya memprioritaskan kebutuhan yang memang dibutuhkan dibandingkan dengan sekedar keinginan atau sering disebut "lapar mata". Selain itu remaja putri sebaiknya dapat menerima kekurangan dan kelebihan yang ada dalam diri sehingga remaja putri dapat mempertahankan harga diri yang positif dan menjadi pribadi yang tidak terperngaruh oleh pengaruh kelompok atau konformitas yang tinggi yang dapat menjerumuskan ke hal-hal yang negatif. Hal ini dilakukan agar remaja tidak terlanjur terjebak dalam perilaku konsumtif dan dapat mencegah terjadinya efek negatif dari perilaku konsumtif yang tinggi, seperti perilaku yang menghalalkan segala cara untuk mendapatkan barang yang diinginkan, misalnya dengan mencuri, atau tindakan kejahatan lainnya.

Bagi orangtua yang memiliki remaja hendaknya memperhatikan kondisi perkembangan anak remajanya dengan cara lebih memahami perubahan kondisi anak tidak hanya dari segi fisik namun dari segi psikis dan sosial, sehingga orangtua lebih mengenal dan memahami pribadi anak remajanya, mengenal dengan baik lingkungan pergaulan atau interaksi sosial anak remajanya di luar keluarga. Orangtua juga diharapkan mampu mengarahkan, membimbing, dan mendidik anak remajanya dengan tetap mempertimbangkan pemikiran dan perasaan mereka sehingga hal tersebut dapat membentuk hubungan yang baik antara anak remajanya dan dapat menghindari pengaruh yang negatif dari lingkungan pergaulannya.

Sementara itu untuk tenaga pendidik untuk mencegah muridnya memiliki sifat yang konsumtif hendaknya memperhatikan dan mengajarkan murid siswinya cara-cara untuk dapat mengontrol perilakunya sendiri, membentuk harga diri positif dengan cara menyarankan murid siswinya untuk mengikuti kegiatan-kegiatan yang positif seperti kegiatan ekstrakulikuler yang dapat mengasah kelebihannya, selain itu guru dan pendidik dapat mengarahkan kepada murid siswinya agar bisa memilah perilaku mengikuti konformitas kelompok yang memberikan pengaruh yang positif yang didapat dari teman-teman sebayanya.

Peneliti juga menyarankan pada peneliti selanjutnya yang ingin meneliti tentang faktor-faktor yang mempengaruhi perilaku konsumtif yaitu memperluas ruang lingkup penelitian lebih lanjut sehingga diharapkan dapat meningkatkan kualitas penelitian. Misalnya dengan memperluas populasi atau melakukan studi banding antara kelompok remaja putri dengan kelompok remaja putra. Hal lain yang perlu diperhatikan adalah menggunakan data tambahan seperti observasi dan wawancara sebagai tambahan acuan dalam menganalisis data, agar hasil yang didapat lebih mendalam dan sempurna, karena tidak semua hal dapat diungkap dengan skala penelitian.

\section{DAFTAR PUSTAKA}

Azwar, S. (2012). Penyusunan skala psikologi (Edisi ke 2). Yogyakarta: Pustaka Pelajar.

Azwar. (1998). Metodologi penelitian, . Yogyakarta: Pustaka Pelajar.

Azwar. (2010). Sikap Manusia manusia teori dan Pengukurannyapengukurannya. Yogyakarta: Pustaka Pelajar.

BPS Provinsi Bali. (2013, Mei 6). Pertumbuhan ekonomi Bali triwulan Tahun 2013. Diunduh dari http://bali.bps.go.id/brs/pdrb/brs_pdrb_05_2013.pdf. Pada tanggal 4 Februari 2014.

Clemes, H., \& Bean, R. (1995). Membangkitkan harga diri anak petunjuk praktis bagi orang tua dan guru. Jakarta: Mitra Utama.

Conger, J. J. (1991). Adolescence and youth; Psychological development in a changing world. 4th edition. New York: Harper Collin publishers.

Coopersmith, S. (1967). The aAntecedentes of sSelf eEsteem. San Fransisco: W. H. Freeman and Company.

Dinas Kominfo Kota Denpasar. (2014). Kondisi ekonomi. Diunduh dari Situs Resmi Pemerintah Kota Denpasar: http://www.denpasarkota.go.id/index.php/selayangpandang/3/Kondisi-Ekonomi. Pada tanggal 4 Februari 2014.

Dwi. (2013, Mei 18). Distro "Serbu" kawasan Panjer saat ramai, omzet tembus hingga Rp 5 juta per hari. Diunduh dari Bisnis Bali: http:/www.bisnisbali.com/2013/05/18/ news/denpasar/nn.html. Pada tanggal 4 Februari 2014.

Dwi. (2013, Mei 18). Distro "Serbu" kawasan Panjer saat ramai, omzet tembus hingga Rp 5 juta per hari. Retrieved from Bisnis Bali: http://www.bisnisbali.com/2013/05/18/news/denpasar/nn.ht $\mathrm{ml}$

Ghozali, I. (2012). Aplikasi analisis multivariate dengan program IBM SPSS 20. Edisi Keenam. Semarang: Universitas Diponegoro.

Ghozali, I. (2013). Aplikasi Multivariate multivariate dengan Program program SPSS. Semarang: Badan Penerbit UNDIP.

Kiliwastisia, A. (2003). Kecenderungan perilaku konsumtif ditinjau dari konformitas pada remaja putri. Semarang: Universitas Katolik Soegidjapranata.

Kristiana, R. (2013, Juli 9). Budaya konsumtif masyarakat PostpostModern modern (1). Diunduh dari Detik Ramadan: http://ramadan.detik.com/read/2013/07/09/071037/2296370 /1522/ budaya-konsumtif-masyarakat-post-modern--1?r771108bcj. Pada tanggal 4 Februari 2014. 
Lina, \& Rosyid. (1997). Perilaku konsumtif berdasarkan Locus locus of Control control pada remaja putri. Jurnal psikologika. 4

Maulana, R. (2013, Oktober 18). Remaja dan perilaku konsumtif. Diunduh dari Kompasiana: http://sosbud.kompasiana.com/2013/10/18/remaja-danprilaku-konsumtif-599965.html. Pada tanggal 5 Februari 2014.

Monk, Knoers, \& Haditomo. (2004). Psikologi perkembangan: Pengantar dalam berbagai bagiannya. Yogyakarta: UGM Press.

Myers, D. G. (2012). Psikologi Sosialsosial. Jakarta: Salemba Humanika.

Nindyati, A. D., \& Indria, K. (2007). Kajian konformitas dan kreativitas Affective affective remaja. Jurnal Proviate, 85107.

Novliadi, F. (2009). Hubungan antara oOrganization-bBased sSelf eEsteem dengan etos kerja.

Papalia, D. E., Sally , O. W., Ruth , F. D., \& Dana , L. (2001). Human development (8th ed.). Boston: McGraw Hill.

Pikunas, L. (1976). Human development an emergent science. Tokyo: Mc Graw Hill Kogakusha ltd.

Purkasih, S. (2008, Oktober 16). Masalah konsumerisme di kalangan remaja. Diunduh dari http://siskapurkasih.blogspot.com/2008/10/masalahkonsumerisme-di-kalangan-remaja.html. Pada tanggal 7 Februari 2014

Santoso, S. (2005). Mengatasi Berbagai berbagai mMasalah sStatistik dengan SPSS versi 11.5. Jakarta: Elex Media Komputindo.

Santrock, J. W. (2007). Adolescence. Dallas: The McGraw-Hill Companies.

Santrock, J. W. (2007). Adolescence. Dallas: The McGraw-Hill Companies.

Santrock. (2003). Adolescence: Perkembangan remaja. Jakarta: Erlangga.

Sarwono, S. W. (2002). Psikologi remaja. Jakarta: Rajawali.

Sears, D. O., Freedman, J. L., \& Peplau, L. A. (1991). Psikologi sosial. Jakarta: Erlangga.

Setiana, R. (2013, April 20). Majalah pendidikan online Indonesia. Diunduh dari Waspadai gaya hidup konsumtif dan Shopaholic!: http://mjeducation.com/waspadai-gaya-hidupkonsumtif-dan-shopaholic/. Pada tangggal 7 Februari 2014.

Siregar, S. (2013). Metode penelitian kuantitatif: dDilengkapi pPerbandingan pPerhitungan mManual dan SPSS. Jakarta: Kencana Prenada Media Group.

Soetjiningsih. (2004). Tumbuh kembang remaja dan permasalahannya. Jakarta: Sagung Seto.

Sugiyono. (2008). Metode penelitian kuantitatif, kualitatif dan R \& D . Bandung: Penerbit Alfabeta.

Sugiyono. (2011). Statistika untuk penelitian. Bandung: Alfabeta.

Sumartono. (2002). Terperangkap dalam iklan: Meneropong imbas pesan iklan televisi. Bandung: Alfabeta.

Surya, F. A. (1999). Perbedaan tingkat konformitas ditinjau dari gaya hidup pada remaja. Jurnal Psikologika, 64-72.

Suryabrata, S. (2000). Metodologi penelitian. Jakart: PT Raja Grafindo Persada.

Suryabrata. (1998). Metode penelitian. Jakarta: Raja Grafindo Persada.
Suyasa, \& Fransisca. (2005). Perbandingan perilaku konsumtif berdasarkan metode pembayaran. 172-198.

Tambunan, R. (2001). Remaja dan perilaku konsumtif. Diunduh dari http:/www.e-psikologi.com/remaja/191101.htm

Vaughan, G., \& Hogg, M. (2002). Social pPsychology (3rd edition). London: Prentice.

Wahyudi. (2013). Tinjauan tentang perilaku konsumtif remaja pengunjung mal Samarinda Central Plaza. eJournal Sosiologi, 26 - 36.

Wardhani, M. D. (2009). Hubungan antara konformitas dan harga diri dengan perilaku konsumtif pada remja putri. Universitas Sebelas Maret: Surakarta.

Yuliantari, M. I. (2014, Februari 5). Perilaku konsumtif pada remaja putri. (Tara, Interviewer)

Zebua, A. S., \& Nurdjayadi, R. D. (2001). Hubungan antara konformitas dan konsep diri dengan perilaku konsumtif pada remaja putri. Jurnal Phronesis, 72-82. 